English Society in the Later Middle Ages

Class, Status and Gender 


\section{English Society in the Later Middle Ages}

Class, Status and Gender

S. H. Rigby 
(C) S. H. Rigby 1995

Softcover reprint of the hardcover 1st edition 1995

All rights reserved. No reproduction, copy or transmission of this publication may be made without written permission.

No paragraph of this publication may be reproduced, copied or transmitted save with written permission or in accordance with the provisions of the Copyright, Designs and Patents Act 1988, or under the terms of any licence permitting limited copying issued by the Copyright Licensing Agency, 90 Tottenham Court Road, London WIP 9HE.

Any person who does any unauthorised act in relation to this publication may be liable to criminal prosecution and civil claims for damages.

First published 1995 by

MACMILLAN PRESS LTD

Houndmills, Basingstoke, Hampshire RG21 2XS

and London

Companies and representatives

throughout the world

ISBN 978-0-333-49240-6

ISBN 978-1-349-23969-6 (eBook)

DOI 10.1007/978-1-349-23969-6

A catalogue record for this book is available from the British Library

$\begin{array}{llllllllll}10 & 8 & 9 & 7 & 6 & 5 & 4 & 3 & 2 & 1\end{array}$

$\begin{array}{llllllllll}04 & 03 & 02 & 01 & 00 & 99 & 98 & 97 & 96 & 95\end{array}$ 


\section{Contents}

Preface ix

Abbreviations xii

Introduction: Social structure as social closure 1

(i) Marxist social theory 2

(ii) 'Liberal' stratification theory 6

(iii) Closure theory 9

\section{PART I CLASS STRUCTURE AS SOCIAL CLOSURE}

1 Agrarian class structure: exclusion and dual closure

(i) Relations of production as social exclusion 18

(ii) Feudal relations of production: exclusion by ownership 21

(iii) Feudal relations of production and extra-economic coercion: the manor, villeinage and monopoly rights 25

(iv) Free peasants 34

(v) Lords, labourers and artisans 37

(vi) Manorial variation: by region and by landlord 40

(vii) Agrarian class structure: gradation and dual closure 45

(viii) 'Extra-economic coercion': some problems 49

(ix) Exploitation and surplus labour: some problems 52

(x) Conclusion: closure, structure and agency 57

2 Agrarian class structure and the forces for change I: trade, population and the money supply 60

(i) The rise of a money economy? 61

(ii) Malthus and Ricardo 66

(iii) Population, the manor and economic change, c.1180-1348 69

(iv) Population, the manor and economic change, $1348-1500 \quad 80$

(v) The 'Malthusian' model: a balance sheet 87

(vi) Prices and the money supply 95

(vii) Conclusion 102 
3 Agrarian class structure and the forces for change II: usurpationary closure 104

(i) Rural class conflict in the pre-plague period 104

(ii) The Peasants' Revolt of 1381110

(iii) Rural class conflict in the post-plague period 124

(iv) Agrarian class structure and economic development: 'the Brenner debate' 127

(v) Conclusion 143

4 Urban class structure and usurpationary closure 145

(i) Urbanisation and its limits 145

(ii) Urban class structure 150

(iii) Borough privileges and town government 160

(iv) Urban social and political conflict: usurpationary closure 165

(v) Conclusion 176

\section{PART II ORDER, GENDER AND STATUS-GROUP AS} SOCIAL CLOSURE

5 Order as social closure I: the nobility 181

(i) Orders, status evaluation and the functional perspective 182

(ii) The functional perspective: some problems 186

(iii) Aristocratic lineage as social closure? 195

(iv) Conclusion 203

6 Order as social closure II: the clergy 206

(i) The clerical order 207

(ii) The clergy: numbers, wealth and power 213

(iii) Clerical status and class structure 223

(iv) Conflict of laity and clergy: usurpationary closure 231

(v) Conclusion 239

7 Gender as social closure: women 243

(i) Ideologies of gender in medieval England 246

(ii) Women in the countryside 252

(iii) Women in the nobility 262

(iv) Women in the towns 270

(v) Women and usurpationary closure 278

(v) Conclusion: a 'deep structure' of social closure? 281 
8 Status-group as social closure: the Jews 284
(i) The Jews and the Crown 284
(ii) The Jews and the Church 290
(iii) 'Popular' anti-semitism 296
(iv) Conclusion 301

9 Social ideology: closure legitimated? 303
(i) The 'dominant ideology' thesis 304
(ii) Theodicy as 'dominant ideology' 306
(iii) Theodicy as social critique 310
(iv) The social dysfunctionality of the
Church's teachings 316
(v) Ideology as 'practice' 320
(vi) Conclusion 322

Conclusion 324

Notes 328

Select bibliography 354

Bibliography of references 357

Index 395 


\section{Preface}

In history, as in the natural sciences, all investigation is 'preceded by a particular interest, a question or a problem - in short, by something theoretical'. The theoretical starting-point of this book is the issue of how best we can make sense of the social relations of medieval England in the period c.1200 to 1500 . What were the main forms of social stratification in late medieval England? To what extent did English society change during these three centuries? What caused such change? Unfortunately, unlike natural scientists in a particular field of research, historians and sociologists who are interested in social stratification possess no dominant paradigm, i.e. an agreed theoretical framework which directs the empirical researches and puzzle-solving of those who work within it. Instead, the most basic questions about the nature of social structure still remain open to debate. Some knowledge of these debates, of the strengths and weaknesses of the conflicting accounts of social stratification currently on offer, and of the social theories which, implicitly or explicitly, underlie existing accounts of medieval English society, is thus essential and it is these debates which provide the focus of this book. The choice confronting us is not whether to be theoretical or not, but whether or not we wish to become aware of the theories which we cannot avoid employing: 'Hostility to theory usually means an opposition to other people's theories and an oblivion of one's own.' Such a conscious confrontation of sociological theory with empirical evidence should be mutually beneficial, allowing us both to see familiar facts about medieval England in a new perspective and to refine our theories so as to arrive at a corpus of concepts which has a relevance for the analysis of other societies apart from late medieval England. ${ }^{1}$

The primary aim of this book is thus to show how a variety of sociological and economic theories have been put to work in the study of medieval England and, through an examination of late medieval social structure, to interrogate and to offer an assessment of the utility of such theories for the historian. This explicit concern with social and economic theory certainly does not mean that facts about the past can be disregarded, that factual evidence can be twisted to fit the theory, or that there is no difference between writing history and writing fiction. In history, as in the sciences, there is always the danger that we will seek evidence which corroborates our hypotheses whilst neglecting that 
which refutes them. However, the public nature of our discipline means that even if we are unwilling to criticise our own theories, other people will always be willing to do so for us. The objectivity of historical knowledge does not, therefore, require the historian to possess some neutral or unbiased private state of mind. On the contrary, subjectively biased minds, armed with particular theoretical searchlights (such as those of Malthus, Marx or Parsons), can often illuminate a new area of the historical landscape. The objectivity of our discipline lies not in some personal character trait or attitude but in the requirement that our hypotheses can be publicly tested against the evidence available to us, in its intersubjectivity. ${ }^{2}$

The second major aim of this book is to show that 'theory' does not only have a background role in providing the hypotheses which historians can then test against evidence. Theory, in the broader sense of the 'philosophy of history', has an equally important role in revealing to us the methodological bases of historical disagreement and debate. Indeed, whilst historians may argue over the facts of some particular situation, their profoundest disagreements are often 'philosophical', for instance, about the nature of historical explanation, rather than factual, even though they themselves might not always be aware that this is the case. The philosophy of history is not, therefore, a separate discipline, separate from the day-to-day concerns of the empirical historian, but lies at the heart of many historical debates.

Naturally, a survey of late medieval society of the kind offered here cannot be a work of original research based on primary sources but must be a synthesis of the work of other historians. If this book has any claim to originality it is in its drawing together of a number of topics which are usually studied in isolation, in its conscious confrontation between empirical history, social theory and the philosophy of history, and, in particular, in its use of 'closure theory' as a framework within which to understand medieval social stratification. Naturally, I have provided many empirical examples to clarify and back-up my claims but, in a work of synthesis of this kind, such examples can, at best, only illustrate particular points rather than prove them. For this reason, I have given full references to my sources so that students can follow up points for themselves in more detail.

Imperial measurements have been used throughout the text and towns and villages have been located in the counties in which they were to be found prior to the local government reorganisation of 1974. Prices are expressed in pounds, shillings and pence (one pound consisted of twenty shillings and each shilling of twelve pence) or in marks (a unit of account worth 13s. 4d.). It is always difficult to compare the value of money at different times but a late thirteenth-century building craftsman, such as a middle-ranking mason or carpenter, would have earned a maximum of $£ 4$ to $£ 5$ a year, a labourer would 
have obtained less than a half of that. A thatcher earning $2 \frac{1}{2} d$. a day in the first decade of the fourteenth century, could have expected to earn $41 / 2$ d. a century later and $5 \frac{3}{4} \mathrm{~d}$. by the start of the sixteenth century. ${ }^{3}$

My thanks are owed to a number of institutions and individuals. I am extremely grateful to the Nuffield Foundation for a one-year Social Science Research Fellowship which gave me the time to research and write this book. I am also indebted to John Breuilly, Jeff Denton, John Hamshere and Ann Hughes, my colleagues at the University of Manchester, who read and criticised draft versions of particular chapters. In particular, I would like to thank those colleagues who were generous enough to devote their own research time to reading the entire book in typescript: Graham Burton, who helped to clarify the overall structure of my argument; Norris Nash, who provided much encouragement at an early stage of writing; and Richard Davies, whose discerning comments forced me to rethink many of my claims. Finally, I would like to thank Rosalind Brown-Grant, of the University of Leeds, for suggesting innumerable improvements to the presentation of the text and for her support throughout the project. Naturally, all of the above are free from any responsibility for the use to which I have put their comments.

S. H. RIGBY 


\section{Abbreviations used in notes and bibliography}

BIHR Bulletin of the Institute of Historical Research

Agric. H. R. Agricultural History Review

$C P L \quad$ Calendar of Papal Letters

CPR Calendar of Patent Rolls

Econ. H. R. Economic History Review

EETS Early English Text Society

EHR English Historical Review

HMC Lynn $\quad$ HMC Eleventh Report, Appendix Part III:

The Manuscripts of the Corporations of Southampton and Lynn (London, 1887)

J. Med. Hist. Journal of Medieval History

Rot. Parl. Rotuli Parliamentorum

SCH Studies in Church History

Statutes $\quad$ Statutes of the Realm, vol. II (London, 1816)

TRHS Transactions of the Royal Historical Society

VCH Victoria County History

NB: References are cited in the Notes by author name, date and page numbers. Full details will be found in the Bibliography of References. 